\title{
The Influence of Traditional Games on The Development of Children's Basic Motor Skills
}

\author{
Ni Kadek Aris Rahmadani \\ Departement of Early Childhood Teacher Education \\ Universitas Negeri Semarang \\ Semarang, Indonesia \\ kaderis@mail.unnes.ac.id \\ Lita Latiana \\ Departement of Early Childhood Teacher Education \\ Universitas Negeri Semarang \\ Semarang, Indonesia \\ kaderis@mail.unnes.ac.id
}

\author{
R. Agustinus AEN \\ Departement of Early Childhood Teacher Education \\ Universitas Negeri Semarang \\ Semarang, Indonesia \\ kaderis@mail.unnes.ac.id
}

\begin{abstract}
The problem is the lack of early childhood games in the school learning, conventional learning games in learning activity. Because development of the modern games have negative affect to motor activity for young children, particularly their movement skills. As a result, many children can't jump with one feet and two feet, bring something through straight line, mention kind of traditional games in Indonesia, especially in Central Java Province. Many kind of traditional games in Indonesia, in this research used engklek game, because this is simple, used "gaco" and engklek area with square line. The aim of this study was to determine the increased development of basic motor skills in group A Pertiwi 49 Ngijo. Basic motor skills in engklek game include three motor aspect such us locomotor, nonlocomotor and manipulative movement. Type of research method used was quantitative research using experiment, preexperimental models, namely one group pretest-posttest. Data basic motor skills before the study obtained by the initial observation for two week and data was collected by score in three aspect.The results showed that the development of basic motor skills of children who experienced a significant increase, amounting to $\mathbf{- 5 . 4 4}$. It can be seen from the results of three aspects on engklek game. Conclusion taken from the research is that traditional game in the learning activity in preschool. This activities can improved motor skills of children, one of them used traditional games because children can played traditional games with the other friend both at school and at home every time.
\end{abstract}

Keywords — traditional game; development of basic motor skill

\section{INTRODUCTION}

Games are one of the means children learning process in kindergarten. Currently, folk games or traditional games are less popular for children, because they know modern games are better. Traditional and modern games have positive and negative impact for motor development young children, particularly their movement skills. The results showed of the observations in aged 3-4 years that learning activities which are related more less to games or motor learning activities in their school. The game does not necessarily have to cost a lot, but it should feature educational aspects which can provide experiences or education for the children. Game activities in school can use games from the regions. Besides playing the games, children can also learn other many traditional games.

Traditional games play a role in children's potential development, such as gross, fine, social, and cognitive motoric development, as well as other aspects of development. Reference [12] show that if there are alternative instructional and curricular models are regarded as more comprehensive and suitable approaches to providing quality physical education. Teachers pointed out that their participation in the programme helped their interpersonal relationships with the other early educators in their schools. According to these teachers, the Early Steps Physical Education Curriculum (ESPEC) model benefited students. In addition, the participants stated that during the implementation of the programme their students learned to communicate and cooperate with each other in a more meaningful way and implications for preparing early childhood educators to teach quality physical education are discussed in light of the results. Teachers can choose the physical activity in this school and activity can make interest and enthusiastic of early childhood.

"Reference [2] have found that children paticipation in early childhood education program benefits the development of childrens verbal and intellectual ability". Because, phisical activities increased childrens curiosity and make notice project, catching, throwing, dropping, shaking, and put in their places. Reference [8] describe that research was intended to develop an innovative conceptual model for early childhood education programs to develop early childhood character through Javanese traditional game. These traditional games had simple rules, easy to apply especially for a toddler. Besides, these traditional games had moral value to build toddler's character. This model has been effectively proven to build toddlers' characters successfully. Teachers actively reviewed the learning outcomes of the children and gave useful inputs for further development for them. Therefore, it is recommended that the socializations of this model should not do by the school only, but also community members especially family. 
Reference [11] states that traditional games partly resembles sports, in which they both have rules, they give pleasure, relaxation, happiness, and challenges. Because childhoods need games in the learning activity every time in school. Reference [7] explain about the relation between gross and fine motor skills and executive functions as well as the relation to possible background variables (SES, physical

Reference [6] showed total 150 children were recruited from four centers which were randomized to intervention or wait-list control group. Six early childhood educators from the intervention centers were trained to deliver the intervention. Gross motor skills were assessed using the Test of Gross Motor Development (2nd edition) and physical activity was measured objectively using GT3X + Actigraph accelerometers. This study highlights the potential of educator-led physical activity interventions and supports the need for further translational trials within the early childhood sector.

Reference [3] the study explain if traditional game can be stimulate of motoric development for early childhood. Traditional games such us bekel, benteng, engklek, lompat tali, hide and seek, gobag sodor and ular naga. Childrens can do more activity with control their muscles, especially hand and feet and learn balance and stability for example jumping, running, throwing, catching coordinate eye, hand and feet and control their fine motor.

Gross motor activities in Pertiwi Kindergarten are commonly done by doing simple activities such as playing slide, climbing ring pole, swings, or running around before children come into the classroom. Gross motor activities are seen from children locomotor, nonlocomotor, and manipulative movements which are not optimum. One of the examples is that children are not yet able to do balanced activities, that is, lifting one foot and move, carrying an object in their hands by walking through a straight line, and jumping with two feet from one box to another. Teachers and parents can stimulate this aspect development with traditional games in Indonesia, especially in Semarang district. This research aims at discovering the improvement of development of basic motion skills of children group A or aged 3-4 years in Pertiwi 49 kindergarten through activities of traditional games. Traditional games used engklek, in this game there are three aspect assessment, such us locomotor, nonlocomotor and manipulative.

\section{RESEARCH METHOD}

This research used experiment method with preexperimental model design that is, one group pretest-postest. Researchers focused observing the improvement of basic motion skills of early childhood, especially for children in group A or aged 3-4 years. This design experiment research are showed belows in table 1 :

Table 1.One Group Pretest-Postest Design

\begin{tabular}{lll}
\hline Pretest & Teatment & Postest \\
\hline O1 & $\mathrm{X}$ & $\mathrm{O} 2$ \\
\hline
\end{tabular}

activity) were investigated. Both, gross and fine motor skills correlated significantly with executive functions, whereas the background variables seemed to have no significant impact on the executive functions and motor skills. Higher order control processes are discussed as an explanation of the relation between executive functions and motor skills.

\section{Explanation:}

\section{O1: pretest before treatment (value of pretest)}

$\mathrm{O} 2$ : postest after treatment (value of postest)

$\mathrm{X}$ : treatment of research subject with traditional game (engklek)

Reference [10] descibe about experimental method as a research method used to discover the influence of certain treatment towards others in a controlled situation. The research swas conducted from Pertiwi Kindergarten located at Jalan Raya Ngijo No2 Guungpati Semarang. The experiment was conducted from April 2016 until September 2016. Reference [5] explain that population is a set of subjects (which includes all living and inanimate objects) with the same tendency as well as the same characteristics. The population in this study is kindergarten from the Gunungpati area. The sampling is done by selecting kindergarten with the suitable criteria. Design used in this research is hypothesis testing, conducted by using paired sample t-Test data analysis. Data collection techniques in this study was conducted through a observation, assessment about three aspect in basic motor development, and documentation of activities. The first observation can describe about the basic motor development in early childhood. Assessment used scoring 1-4 in three aspect motion data collect. And documentation collecting by researchers from observation photos or video motor activities using traditional game engklek in early childhood Pertiwi Kindergarten.

\section{RESULTS AND DISCUSSIONS}

Sampling is done within one month and the data obtained are wholly the data calculation of locomotor, nonlocomotor, and manipulative movements. Results of the data showed that there has been a change in the mean score before and after the engklek treatment, that is, increases mean from 5,63 to 11,08 . This change of mean score on the calculation result which is 5,44 is difference of average of development of basic motor skills before and after the treatment. The significance value of $\mathrm{p}$ is 0,026 , meaning that the value of $\mathrm{p}<0,05$, meaning that it is significantly different. From the calculation results of children basic motion skills, it is discovered that t-calculation is $-39,873$. Thus, treatment of traditional games can improve basic motion skills of children from group A.

A research conducted reference [4] shows that the process of playing traditional game can effectively improve children gross motor skills. Traditional games require hand coordination, hand and body coordination. The games played inside or outside the room can improve the development of children basic motions. These basic motions are moves every child has to make to continue their motor development in the next age. Even though every child goes through different 
developments at different times, they will still go through the same stages of motor development. Besides improving the development of children basic motion skills, it also introduces many fun, easy, inexpensive, and simple traditional games which can basic motions, it is discovered that activities of fun games in kindergarten influence the development of children motor skills, which are, children basic motion skills that are used as a reference of early development of the next children motor development.

Reference [1] research are to know the improving of gross motor skills in early childhood through traditional games of Banten. The result of the study show increasing of gross motor skills significantly by positive respons of traditional games of Banten. And the teacher can give spirit of the child in following gross motor learning after through traditional games of Banten such us bebentengan and edom-edom tugel, this games to be a new solution to improve gross motor skills of childhood in the learning activity.

Research conducted by reference [9] show if gross motor skills that will be assessed are aspects of locomotor movements include running and walking, nonlokomotor movement include standing, holding and bending, and manipulative movement include catch and roller. The implication of the research, traditional Javanese games, can make learning motor skills become more easy and fun, tradisional Javanese games should be alternative to teach gross motor skill for the children.

Based on the result of this research, the development of motion skills, in term of aspect of children locomotor, nonlocomotor, and manipulative basic motions have had changes before and after playing traditional game engklek.

In engklek game, there are three aspects, they are locomotor, non-locomotor, and manipulative basic motions. Locomotor basic motions in engklek are aspects of hopping and jumping. That is, hopping through various boxes with one foot and jumping with two feet when children are in the middle or end of one round of the game. Children are able to coordinate between eyes and feet so that they do not touch the border line in engklek game. Nonlocomotor basic motions in engklek game are standing straight, spinning around, spinning by changing the position of direction, bowing when throwing" gaco" to one of the boxes, landing when on child has made one round, turning around the gaco from palm of the hand to back of the hand, swinging hands, and keeping in balance when jumping. Manipulative basic motions include throwing gacuk to the aimed box, grabbing it, and carrying it ("gaco" is a shrapnel or block pieces).

Teachers can provide alternatives of learning activity using traditional games, so the children can learn about various games in Indonesia Thus, they can also play the games not only in school but also at home. Therefore, children have alternatives to other games besides modern games which are currently developing. The named of traditional games in area Indonesia is different one with another, but played this game and tools needed are same. Because, the named traditional games according local language.

\section{CONCLUSION}

The conclusion of this research as follows: the influence traditional game on the development motor skill early childhood about three aspect in engklek game, such us: 1) aspect lokomotor, consist of hopping and jumping 2) aspect nonlokomotor consist of standing straight, spinning around, spinning by changing, and 3) aspect manipulative consist of throwing gacuk in a box. Three aspect can developing with traditional game, one of them is engklek and can played physical learning activity in the school or daily activity at home with other friends. Introducing for early childhood if Indonesia have many traditional games and culture in every region.

\section{Acknowledgement}

Thanks to LP2M support the author financial as a research grant and thanks alot of to Pertiwi 49 Kindergarten for their to be a place of our research.

\section{References}

[1] Alawiyah, R.T. (2014) Peningkatan Keterampilan Motorik Kasar Melalui Permainan Tradisional Banten. 8 (1), hh. 175-184.

[2] Dirjen PLS. (2007). Media Informasi Pendidikan Nonformal (PAUD Masih Dipandang Sebelah Mata), Jakarta: Warta Plus.

[3] Efendi, Dwi Imam. (2015) Permainan Tradisional Sebagai Media Stimulasi Aspek Perkembangan Fisik Motorik Anak Usia Dini. Jurnal Didaktika, 13 (3), hh.11-18.

[4] Fatimah, EN dkk. (2015). Mengembangkan Motorik Kasar Melalui Permainan Tradisional Jawa Barat, Jurnal Universitas Pendidikan Indonesia, 1.

[5] Handini, Myrnawati Crie. (2012). Metodologi Penelitian untuk Pemula, Jakarta: FIP Press.

[6] Jones, Rachel A, et al. (2016). Promoting Gross Motor Skills and Physical Activity in Childcare: Translational Ramdomized Controlled Trial. Journal of Science and Medicine in Sport. 19 (9), pp. 744-749.

[7] Oberer, Nicole, Venera Gasshaj \& Caludia M. Roebers. (2017). Motor skills in kindergarten: Internal structure, cognitive correlates and relationships to background variable. Journal Human Movement Science, 5, pp.170-180.

[8] Pranoto, Y.K.S, Sugiyo, \& Hong, J. (2014). Young Children Character Development Through Javanese Traditional Game. Indonesian Journal of Early Childhood Education Studies, 3 (1), pp. 54-58.

[9] Rahmadani, N. K. A. (2014). Peningkatan Keterampilan Motorik Kasar Melalui Permainan Tradisional Jawa. Jurnal Pendidikan Usia Dini, 8 (2), hh. 305-314.

[10] Sugiyono. (2010). Metode Penelitian Pendidikan Pendekatan Kuantitatif, Kualitatif, dan $R \& D$. Bandung: Alfabeta.

[11]Tientje. (2004). Pendidikan Anak Usia Dini. Jakarta: Darma Graha Group. 
[12]Tsangaridou, Niki \& Nicholas Genethliou. (2014). Early Childhood Educators Experience of an Alternativie Physical Education Model. Europen Early Childhood Education Research Journal. 24 (3), pp.382397. 